\title{
Why (Not) World Literature
}

\section{Challenges and Opportunities for the Twenty-First Century}

\author{
Karen L. Thornber \\ Harvard University \\ thornber@fas.harvard.edu
}

\begin{abstract}
Increasing attention to the enduring processes of cosmopolitanism, globalization, and transnationalism, together with growing frustration with the geographic, linguistic, and conceptual limitations of many fields of literature, has led in the past two decades to burgeoning interest in the discipline of world literature. Institutes, conferences, articles, volumes, and journals on various aspects of world literature are proliferating around the world as never before. But the challenges facing world literature remain significant. One of the largest is the field's continuing biases, and in particular its tendency-despite its name-to privilege literature that not only has been embraced by Western readers but also conforms to the expectations of Western scholars. Just as important is the failure of world literature to integrate the study of literature more comprehensively with urgent matters of global significance. The pages below elaborate on the first challenge and address the second, identifying several opportunities going forward.
\end{abstract}

\section{Keywords}

Asia - Roberto Bolaño - Dandin - Gesar - Murakami Haruki - Adaobi Tricia Nwaubani

For most of its history, the field of world literature has been associated with an established canon of primarily Western European classics and masterpieces. Goethe might have recognized that the Chinese were writing prolifically while "our ancestors were still living in the woods"; but he also grossly essentialized Chinese literature and furthermore warned that "Looking for models, we must always return to the ancient Greeks, in whose works the beauty of humankind is constantly represented" (Eckermann 322-25). As Werner Friederich lamented 
in 1960, "Sometimes, in flippant moments, I think we should call our programs NATO Literatures-yet even that would be extravagant, for we do not usually deal with more than one fourth of the 15 NATO-Nations" (Friederich 15). And, as recently as 1990, most North American university courses continued to follow this model (Damrosch "Introduction" 1), and some continue to do so today. In fact, only in the last few years has the Modern Language Association made a concerted effort to include a broad array of literatures in its series Approaches to Teaching World Literature; of the 133 titles currently available, a mere 5 are from non-Western languages, with only an additional 5 from outside Europe and the United States. ${ }^{1}$ The same dynamic has been true in other parts of the world. To give one example, until the last decade, Japanese multi-volume collections of world literature (sekai bungaku 世界文学), which date to the turn of the twentieth century with the eleven volume Tsüzoku sekai bungaku (通俗世界文学, Popular World Literature, 1903-4) and have been far more comprehensive than many of their Western counterparts, focused largely on European classics and masterpieces. ${ }^{2}$

Over the years, many scholars-partly in an attempt to introduce greater geographic and linguistic flexibility into the field — have identified circulation beyond origins as a key criterion for world literature. As David Damrosch writes in What is World Literature?: "I take world literature to encompass all literary works that circulate beyond their culture of origin either in translation or in their original language ... World literature is ... writing that gains in translation" $(4 ; 281) \cdot{ }^{3}$ In theory, then, lack of notice from Western translators and readers

1 Given the volumes in preparation and under contract for this series, there is likely to be a notable uptake in these numbers in the coming years. Of the European texts in Approaches to Teaching World Literature, nearly all are from Western Europe.

2 For a genealogy of Japanese anthologies of world literature, see Akikusa. An important early exception is Hutcheson Macauly Posnett's 1886 definition of world literature in "What is World-Literature" - "The leading mark of world-literature ... is the severance of literature from defined social groups - the universalizing of literature," a process he argues is as visible in Indian and Chinese literatures as in Hebrew and Arab literatures and for that matter European literatures (236). Also noteworthy in this context is the Slovakian critic Dionýz Ďurišin's own Čo je svetová literatúra (What is World Literature), which focuses more on North American and Eastern and Western European literatures than it does literatures from other regions, but calls attention to the world's numerous inter-literary communities connected via ethical, ideological, linguistic, political, regional, or religious frameworks. Thank you to Nina Begus for this observation.

3 The concept "culture of origin" is problematic, since many works of literature, or at least their component parts, have "origins" in multiple cultural spaces. So too are the subjective notions of "gaining" and "losing" in translation. 
does not preclude a creative work from being considered a work of world literature. But in practice, scholars of world literature have tended to limit themselves to texts that have circulated in, and at times only in, Western languages. In his 1940 essay "What is World Literature?" Albert Guérard urges readers to "enjoy the best, wherever the best may be found" but then goes on to claim that world literature is "those works which are enjoyed in common, ideally by all mankind, practically by our own group of culture, the European or Western" (3-16). As Kan Wang has observed, today more than ever, "[Because] the hierarchy privileging Western language literature has become increasingly solidified ... [non-Western writers] cannot enter into the ranks of 'universal writers' without recognition from the West" (571). So while a work that has circulated only in Europe generally would be discussed as world literature, a work that has circulated only in Asia-a collection of far more diverse cultures with close to sixty percent of the world's population and nearly six times the number of people as Europe-frequently would not.

Yet even non-Western works that have been translated into Western languages tend to be overlooked by scholars of world literature when these works fall outside contemporary expectations. One striking example is the Tibetan

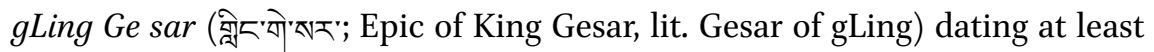
from the twelfth century. ${ }^{4}$ Twenty-five times the size of the Iliad, Gesar is the world's longest epic, a massive narrative of more than one million lines of poetry that has traveled over the centuries in numerous and often very distinct forms, both in written translation into numerous Asian and European languages and via a dynamic oral tradition that continues to this day in Tibet, Nepal, India (Ladakh), Mongolia, Russia, and elsewhere in central Asia, in addition to numerous ethnic groups within China (Bender 145). However, Gesar has not been discussed as world literature and is not included in anthologies of world literature. ${ }^{5}$ Instead, world literature scholarship on Tibet has focused on the more accessible Mandarin Chinese- and English-language contemporary ethnic Tibetan writers such as Tashi Dawa, Alai, and Jamyang Norbu.

The case of India is just as noteworthy. An excellent example is South Indian poet and scholar Daṇ̣in's groundbreaking Sanskrit work on poetics Kāryādarśa (काव्यादर्श, Mirror of Poetry, 700), which has been translated into numerous South Asian, Southeast Asian, and Central Asian languages, continues even

4 There is no one definitive version of the title of this epic. Thank you to Norzin Dickyi for this observation.

5 For more on Gesar as world literature see Thornber. 
now to impact literary production from Tibet to Sri Lanka and throughout India, and is believed to be "one of the most influential treatises ever produced in Asia"; some have argued that the Mirror of Poetry also made a mark on Chinese poetics. Despite its success within Asia, and its having been translated into several European languages, Mirror of Poetry is not discussed as world literature (Lasting Vision). ${ }^{6}$ Moreover, the critical and commercial acclaim surrounding Salman Rushdie and most notably his Midnight's Children (1980) has confected out of this novel "a gigantic edifice that all but obstructs the view of what lies behind" (Chaudhuri xvii). This in turn, to cite Francesca Orsini, has

created a highly prescriptive set of assumptions ... [all of which] ride roughshod over ancient and modern [Indian] traditions ... The West's 'discovery' of Indian fiction since Midnight's Children has served to obscure rather than to illuminate some of the most interesting aspects of subcontinental literature ... The West [contemplates] ... not India, but its latest reinterpretation of itself.

$319-20,331$

Orsini gives Phanīshwar Nāth Renu's Hindi-language Mailā ã ñcala (मैला आँचल, Soiled Border, 1954) as a good representative of Indian literary production; this novel has been translated into multiple languages and circulated broadly, yet its subject matter makes it anathema to Western sensibilities of what the corpus of Indian literature is or should be and so for the most part has been overlooked in world literature scholarship.

Important in this context as well is the case of Latin America and magical realism, a genre that has received disproportionate attention and manipulation. As Mariano Siskind has argued,

Magical realism goes global as a particularistic aesthetic that satisfies a demand for local color from marginal cultures in the global field of world literature ... Genres and texts belong to world literature not because of what they are but rather because of what they $d o$ : because they perform global desires, because they further transcultural goals ... I insist on the notion of world literary interventions ... [that redraw] the boundaries of the world.

61

6 Thank you to Tyler Richard for this reference. 
Although Siskind's focus is on world literature as critical discourse, not as circulation, magical realism - a concept first developed in Europe — naturally encompasses both.

Yet the challenges stem even deeper. Ironically enough, the emphasis on circulation - and especially on circulation in privileged Western marketsexcludes from world literature the vast majority of the world's texts and many of its flourishing genres. Harish Trivedi criticizes Franco Moretti for emphasizing, in "Conjectures on World Literature" (2000), the sub-genre of the novel, and in particular its global Western manifestations, rather than focusing on the broader form of the narrative, with which a larger variety of communities engaged for far longer. The point is well taken, but there are many additional genres and forms of writing that could be probed just as productively, including, for instance, bitextual slesa poetry from India, which flourished between the sixth and sixteenth centuries, in the context of literary experimentation more generally. As Yigal Bronner notes, "Western literary theorists, who have only recently begun to consider wordplay and puns as a worthy object of serious interrogation, are totally unaware of the existence of slesa, undoubtedly the greatest experiment with such poetic devices in the history of world literature" ("Extreme Poetry"). ${ }^{7}$

Even more significant, the emphasis on circulation disproportionately disadvantages those communities, indeed continents, whose texts have far fewer opportunities to circulate in the first place. Two of the more common obstacles to circulation are stereotypes (extant texts do not circulate, are not translated, because they do not appeal to Western consumers) and the fragility, or even disintegration, of physical materials (extant texts disappear before scholars can access them). To give one example, India has a classical corpus of millions of texts, one that is many times the size of the Greek and Roman legacy, but all but a very small percent of ancient Indian works exist solely in manuscripts that are decaying faster than they can be catalogued (Dalrymple). Most of these materials cannot be accessed by specialists, much less by scholars of world literature. The new Murty Classical Library of India, more than a century overdue given the establishment of the Loeb Classical Library in 1911, promises to change this situation, bringing hundreds of volumes to light. Sheldon Pollock claims that far from catering to Western tastes, the Murty Classical Library, which will have

7 See also Bronner (Extreme Poetry). Countless genres have been overlooked (including the Korean sijo) while others have been overemphasizsed (including the Japanese haiku). As a number of scholars have noted, the emphasis on periodization on Western terms also distorts much of the global literary corpus. 
the original scripts on alternate pages, "will be shocks of unfamiliarity ... [and will require] the reader's willingness to be completely surprised" (Ireland).

The contemporary Nigerian novelist Adaobi Tricia Nwaubani is perhaps more realistic than Pollock in her assessment of how readers react to surprise. Nwaubani recently expressed relief that "African voices are finally telling African stories." But she quickly added:

We are telling only the stories that foreigners allow us to tell ... It appears that publishers have allotted Africa the slot for supplying the West with savage entertainment ... The same stereotypes Africans often claim to abhor tend to form the foundations for our literary successes ... Some of the greatest African writers of my generation may never be discovered, either because they will not reach across the Atlantic Ocean to attract the attention of an agent or publisher, or because they have not yet mastered the art of deciphering Western tastes. ${ }^{8}$

This state of affairs is nothing new; nearly twenty years ago it prompted the South African Nobel Prize winner Nadine Gordimer, despite her own success on the world stage, to ask, "In the all-encompassing sense of the term 'world', can any of our literatures be claimed definitively as 'world' literature? Which world? Whose world?" (521). Gordimer called for a pan-African network of publishers and distributors who would cooperate "to make our writers' work as prominently and naturally available as the Euro-North American potboilers which fill airport bookstalls" (526). But the problem is that many African publishers, in the words of Nwaubani, "tend to prefer buying rights to books that have already sold in the West" (3). So to circulate even within Africa often requires a writer to adhere to Western expectations of African literature. ${ }^{9}$

8 As Bady argues, "If [the Nigerian-American writer] Teju Cole writes about Lagos, will The New York Times warm to it in quite the same way as it has to his novel about an African in New York City? If not, it will be for reasons that will have everything to do with the NYT's own parochial perspective."

9 Often, but not always. The internet is changing publishing globally, including in Africa, where in 2013 the South African lawyer, novelist, and Harry Potter fan Mike Maphoto's blog Diary Of a Zulu Girl - the fictionalized online story of Thandeka Mkize, a girl from rural Kwa-Zulu Natal who, like so many protagonists in southern African literature since the late 180os, travels from country to city (in this case to study law at the University of the Witwatersrand, Johannesburg) — had 33 million hits from 22 countries and was self-published as a book (Bosch-Santana 254). For more on online publishing in Africa, see Adenekan and Cousins. 
Certainly one of the principal contributions world literature scholarship can make henceforth is to unearth the many upcoming, under-, and even unexamined vectors of literary travel as well as the barriers to travel and those texts that are buried or at least barricaded by such barriers. The emphasis here needs to be on search and retrieval, on unearthing, not on calling even more attention to texts and contacts that have already attracted considerable notice. Trivedi has harsh words for how circulation has figured thus far into world literature scholarship:

If World Literature is no more than 'a mode of circulation and of reading' it need involve no more than what we are reading anyhow because it is already in circulation. There is no rescue involved here and no recovery or discovery, no widening of horizons and no reaching out, but a mere passive responsive capacity and readiness to pick up whatever is washed up to our doorstep by the tides of global market forces or the quirks of literary transmission and translation. While we readers of World Literature just sit there, it is any book that aspires to become part of World Literature that must do all the running, and it must furthermore 'suddenly leap out with a freshness and vivid realism to which we can immediately respond'.

Trivedi overstates the case, but his critique of the potential passivity of world literature scholarship is justified.

In the future, scholars of world literature need to do more first to identify and then to probe the contacts that do not wash up to our doorsteps or even to the outer borders of our comfort zones, in other words, those that require us to do a bit more venturing out into the world, including research in the archives. Principal among the lesser-explored networks are those both within large multilingual regions, especially Africa and South Asia, but also Central, East, and Southeast Asia, Latin America, and lesser-discussed parts of Europe; and those that involve multiple non-European regions (e.g., Global South; East Asia and the Indian Ocean Rim, including China and Africa), as well as vectors that involve writers worldwide that have not (yet) achieved global stardom. ${ }^{10}$ In other words, to give one example, while more comprehensive studies of East

10 Some literary pathways within and among these regions are already well known-including those of premodern East Asia, and those between early China and India—but many more remain to be analyzed. There are also numerous cultural connections among the lesser-discussed parts of Europe and many non-European regions, among the best known of which is the Chinese writer Lu Xun's interest in Eastern European literature. 
Asian-Latin American literary relations are long overdue, it is not enough simply to speak of how widely writers such as Murakami Haruki are read in Latin America and how popular writers such as Roberto Bolaño have become in East Asia. As Héctor Hoyos has lamented, "In many circles, Bolaño has come to represent the entirety of contemporary Latin American literature and its contribution to world literature" (Winterbottom). ${ }^{11}$ The same is true for the most part of Murakami Haruki and Japan. Instead of focusing solely on these and similar writers, we must also take into consideration the many other individuals whose works travel between these two sites and frequently many more. Additionally providing a clear counterpoint to the center-periphery model of world literary circulation are the circuits of modern Jewish-language literatures that Lital Levy and Allison Schachter have uncovered, "composed of multiple centers in Asia, Africa, Europe, and North America" (93). ${ }^{12}$

But ultimately, any field that claims the "world" needs to place these networks in the context of the countless texts that have traveled only very short distances. Often just as important as why and how some texts become known across communities and languages is why and how the vast majority do not. And exploring these dynamics requires that we step even further beyond the familiar, thinking more, for instance, about how texts that take readers to different parts of the world do not necessarily themselves travel the world-how writers from Kenya, Malawi, South Africa, Zimbabwe, and other parts of Africa are grappling with China in their work in light of Chinese incursion into Africa and the paradoxically marginal position of such texts in Chinese-African literary vectors; the barriers to circulation facing texts that deal with circulation, including the Kuwaiti novelist Sa'ūd Al-San'ūsī's Sāq al-bāmbü (ساق البامبو, Bamboo Stalk, 2012), which features the place of diasporic Southeast Asian workers in the Middle East. ${ }^{13}$

Venturing outside well-known territory carries with it numerous risks, two of which are that we simplify texts beyond recognition, often accentuating stereotypes and engaging in tokenism, or that in trying to sound scholarly and

11 Hoyos describes world consciousness in Latin American writers such as César Aira, Mario Bellatin, Diamela Eltit, Chico Buarque, Alberto Fuguet, and Fernando Vallejo. See also Siskind.

In tracing the circulation of texts in Jewish literary contacts, Levy and Schachter discover a mode of world literature "tied to practices of translation between 'minor' (nonmetropoli$\tan$ ) languages." They admit that this literary configuration might not encompass "the world," but its "transnational networks of linguistic and cultural exchange provide a clear counterpoint to the center-periphery model of global literary circulation" (93).

Thank you to Stephanie Bosch-Santana and William Granara for these references. 
unwilling to acknowledge the lacunae in our own training, we make assertions that cannot be substantiated. The former frequently results from attempting to appeal to a broad audience, while the latter often is a consequence of our simplistic overreliance on translations that, often unbeknownst to us, distort their sources. Greater humility is called for here. When working on texts, writers, literatures, and cultures whose languages we cannot read, collaboration is imperative. And if for whatever reason we cannot get expert feedback on our work before it goes public, we need to indicate clearly what we are reading in which language, where the foundation for our arguments lies, and what resources we would have benefited from having. The more world literature scholarship distorts literatures, the more it repels the very specialists with whom it needs to create alliances to be legitimate; as is true of world/global history, the very best world literature scholarship incorporates discussion both of large-scale processes and of their specific inflections in particular settings, combining the global, the local, and everything in-between (Bentley 4). As is well known, the field of comparative literature has often been accused of dilettantism; the charges against world literature are even greater, given that the field presumably enables even someone who simply cherry-picks bestsellers from various sites to claim to do the "world." These charges will not be easily dismissed, but mitigating them should not be as burdensome as we might fear.

An equally serious accusation that continues to haunt world literature scholarship and humanities scholarship more generally is relevance, and indeed, scholarship on world literature has remained relatively silent on many matters of global significance. ${ }^{14}$ To be sure, scholars of world literature have for decades engaged with certain fundamental social and political concerns. But with several notable exceptions, world literature scholarship has not fully addressed the relationship between world literature and such global problems as human rights abuses, trauma, poverty, slavery, environmental degradation, and health and disease; there has been very little engagement between world literature scholarship and that on global history, or the digital, environmental, medical, and public humanities. ${ }^{15}$ After two generations of great concern with the tensions and problems of the Cold War, and of neocolonialism and neoliberal economic expansion, it is now appropriate for world literature scholarship to deal more rigorously with a broader range of global issues. In our era of multiple accelerating transnational challenges, not to mention anemic humani-

\footnotetext{
14 See Bod for an overview of the substantial contributions of the humanities through time and space.

15 For exceptions see, Anker; Harlow (Resistance, Barred); Nixon, among others.
} 
ties enrollments, world literature scholarship must connect more meaningfully with life on the ground, with the ultimate goal not only of deeper engagement with a broader array of texts, pathways, and processes than ever before, but also of providing much needed insights into global problems and ideally working toward their amelioration.

\section{Works Cited}

Adenekan, Shola and Helen Cousins. "African Short Stories and the Online Writing Space." In The Postcolonial Short Story: Contemporary Essays, eds. Maggie Awadalla and Paul March-Russell. New York, NY: Palgrave Macmillan, 2013, 199-213.

Akikusa, Shun'ichirō. "Kanon o hakaru: 'Sekai bungaku zenshū' ni miru kakkokubetsu bungaku no juyō no utsuri kawari." Sekai bungaku 120 (December 2014), 65-76.

Anker, Elizabeth S. Fictions of Dignity: Embodying Human Rights in World Literature. Ithaca, NY: Cornell University Press, 2012.

Bady, Aaron. "What It Takes to Build Your Credit: 'Urban Zoning,' by Billy Kahora, Week Two of Blogging the Caine." The New Inquiry Online, May 18, 2012.

Bender, Mark. "Ethnic Minority Literature." In The Columbia History of Chinese Literature, ed. Victor Mair. New York, NY: Columbia University Press, 2001, 1032-1054.

Bentley, Jerry H. "Regional Histories, Global Processes, Cross-Cultural Interactions." In Interactions: Transregional Perspectives on World History, eds. Jerry H. Bentley et al. Honolulu, HI: University of Hawaii Press, 2005, 1-13.

Bod, Rens. A New History of the Humanities: The Search for Principles and Patterns from Antiquity to the Present. New York, NY: Oxford University Press, 2013.

Bosch-Santana, Stephanie. "Forms of Affiliation: Nationalism, Pan-Africanism, and Globalism in Southern African Literary Media." PhD dissertation, Harvard University, 2015 .

Bronner, Yigal. "Extreme Poetry (The South Asian Movement of Simultaneous Narration)." Online resource: www.exoticindiaart.com/book/details/extreme-poetrysouth-asian-movement-of-simultaneous-narration-NAG539/

Bronner, Yigal. Extreme Poetry: The South Asian Movement of Simultaneous Narration. New York, NY: Columbia University Press, 2010.

Chaudhuri, Amit. "Introduction." In The Picador Book of Modern Indian Literature, ed. Amit Chaudhuri. London: Picador, 2001, xvii-xxxiv.

Dalrymple, William. "Review of The Norton Anthology of World Religions, vol. .." The New York Times Sunday Book Review online, December 19, 2014.

Damrosch, David. "Introduction: All the World in the Time." In Teaching World Literature, ed. David Damrosch. New York, NY: The Modern Language Association of America, 2009, 1-11. 
Damrosch, David. What is World Literature? Princeton: Princeton University Press, 2003.

Ďurišin, Dionýz. Čo je svetová literatúra? Bratislava: Vydavatel'stova Obzor, 1992.

Eckermann, Johann Peter. Gespräche mit Goethe in den letzten Jahren seines Lebens. Leipzig: F.A. Brockhaus, 1837.

Friederich, Werner. "On the Integrity of Our Planning." In The Teaching of World Literature, ed. Haskell Block. Chapel Hill, NC: University of North Carolina Press, 196o, 9-22.

Gordimer, Nadine. "The Status of the Writer in the World Today: Which World? Whose World?" In Telling Times: Writing and Living, 1954-2008. New York, NY: W.W. Norton \& Co., 2010.

Guérard, Albert. Preface to World Literature. New York, NY: Henry Holt and Company, 1940.

Harlow, Barbara. Barred: Women, Writing, and Political Detention. Middletown, ст: Wesleyan University Press, 1992.

Harlow, Barbara. Resistance Literature. New York: Methuen, 1987.

Hoyos, Héctor. Beyond Bolaño: The Global Latin American Novel. New York, NY: Columbia University Press, 2015.

Ireland, Corydon. "A Literary Colossus." Harvard Gazette online, March 4, 2015.

Lasting Vision, the. "A Lasting Vision: Dandin's Mirror in the World of Asian Letters." www.as.huji.ac.il/content/lasting-vision-dandin\%E2\%80\%99s-mirror-worldasian-letters-o

Levy, Lital and Allison Schachter. "Jewish Literature/World Literature: Between the Local and the Transnational." PMLA 130:1 (January 2015), 92-109.

Nixon, Rob. Slow Violence and the Environmentalism of the Poor. Cambridge, MA: Harvard University Press, 2011.

Nwaubani, Adaobi Tricia. "African Literature for Western Eyes." The New York Times Sunday Review, November 30, 2014, 3.

Orsini, Francesca. "India in the Mirror of World Fiction." In Debating World Literature, ed. Christopher Prendergast. New York, NY: Verso, 2004, 319-33.

Posnett, Hutcheson Macaulay. Comparative Literature. London: K. Paul, Trench, 1886.

Siskind, Mariano. Cosmopolitan Desires: Global Modernity and World Literature in Latin America. Evanston, IL: Northwestern University Press, 2014.

Thornber, Karen L. "The Many Scripts of the Chinese Scriptworld: Tibet's Epic of King Gesar and World Literature." Journal of World Literature (forthcoming).

Trivedi, Harish. "Comparative Literature, World Literature and Indian Literature: Concepts and Models." In Interdisciplinary Alternatives in Comparative Literature, eds. E.V. Ramakrishnan et al. New Delhi: Sage Publications, 2013, 17-34.

Wang, Kan. "North America, English Translation, and Contemporary Chinese Literature." Frontiers of Literary Studies in China 6:4 (December 2012), 570-81. 
Winterbottom, Tom. "Latin American Authors Reshaping World Literature." Stanford News online, May 21, 2015.

Yeh, Catherine Vance. The Chinese Political Novel: Migration of a World Genre. Cambridge, MA: Harvard University Press, 2013. 